\title{
Description of students' science process skills on density material
}

\author{
Tanti Tanti *, Dwi Agus Kurniawan, Aziza Putri Ningsi \\ Universitas Islam Negeri Sultan Thaha Saifuddin. Jl. Arif Rahman Hakim No.111, Jambi 36124, Indonesia \\ Universitas Jambi. Jl. Raya Jambi - Muara Bulian KM.15, Muaro Jambi, Jambi, Indonesia \\ * Coressponding Author. E-mail: tanti@uinjambi.ac.id
}

Received: 12 August 2020; Revised: 9 September 2020; Accepted: 22 September 2020

\begin{abstract}
Physics is one of the subjects related to various scientific concepts in which some of its applications can be found in everyday life. Thus in the learning of physics required special skills, namely science process skills. Science process skills have two categories, basic science process skills and integration of science processes. The researcher conducted research that aims to measure the ability of students' science process skills on static fluid material by using an observation sheet that matches the indicators of science process skills. The research method used is a mixed-method (mix methods), while the design used is sequential explanatory, which combines quantitative and qualitative research in a sequence using the quantitative method and then the quantitative method. From the results of interviews and observations, it can be seen that the science process skills of students at Adhyaksa 1 Junior High School in Jambi are classified as good.
\end{abstract}

Keywords: Physics; Skills; Science process skills

How to Cite: Tanti, T., Kurniawan, D., \& Ningsi, A. (2020). Description of students' science process skills on density material. Jurnal Inovasi Pendidikan IPA, 6(2), 156-164. doi:https://doi.org/10.21831/jipi.v6i2.33862

\section{INTRODUCTION}

Education can be a conscious effort to shape human potential as the participants do by teaching and facilitating student learning activities (Astalini, Kurniawan, \& Sumaryanti, 2018). Education is an activity carried out by someone to gain knowledge, skills, and habits in life (Asrial et al., 2019). Important activities in the learning process are parts of education (Darmaji, Kurniawan, Astalini, \& Nasih, 2019). Education in Indonesia has progressed well and still needs more development (Astalini, Kurniawan, \& Putri, 2018). To advance and develop students' abilities can be done by guiding, paying attention, and providing learning activities (Astalini, Kurniawan, \& Putri, 2018). Informal education, science is an important study. Science is not only mastery of a collection of knowledge in the form of facts, concepts, or principles, but also is a process of discovery (Rosa, 2015). Natural Sciences consists of several fields of learning, one of which is Physics.

Physics is one of the subjects related to various scientific concepts in which some of its applications can be found in everyday life (Putra et al., 2019). physics is also a branch of science that studies matter and energy and how they interact with each other (Yediarani et al., 2019). Physics is one branch of natural science that is fundamental for students to understand the natural phenomena that occur around them (Sambada, 2012: 38). There are still many weaknesses to learning physics in developing the ability to reason and think inductive and deductive analysis using physics concepts and principles (Halim, 2012, p. 143). Physics does not only learn theories or facts about natural phenomena, but also physics needs to understand how to find physical concepts. Thus in the learning of physics required special skills, namely science process skills.

Science process skills are all abilities needed to acquire, develop, and apply scientific concepts, principles, laws, and theories in mental, physical, and social abilities (Yuliati, 2016). Science process skills are thinking skills that help students learn through knowledge to solve problems and find solutions (Darmaji, Kurniawan, Suryani, et al., 2018). Science process skills have two categories, basic science process skills and science process integration skills (Hırça, 2012). Process skills consist of basic skills, where these basic skills will be the basis for further skill development (Darmaji, Kurniawan, \& Lestari, 2018). Basic science process skills consist of observing, classifying, predicting, measuring, inferring, and communicating (Raj \& Devi, 2014). Integrated science process skills can be mastered after mastering the basic process skills. Integration science process skills include: identifying variables, making data 
tables, making graphs, describing relationships between variables, collecting and organizing data, analyzing experiments, making hypotheses, defining variables operationally, designing experiments, conducting experiments (Chabalengula et al., 2012).

One of the causes of the learning process's success is influenced by the quality and way of teaching teachers. The research results by (Maison et al., 2019) found students and teachers who had not yet mastered the science process skills, so it was necessary to develop science process skills in education. Teachers teach using conventional methods to eat students only know the physics concepts alone without knowing how to obtain these concepts (Ningsi \& Nasih, 2020). Teaching using traditional methods makes students learn passively and can not build knowledge independently (Aydın, 2013). This way of thinking can lead to a low level of students' science process skills when teachers can only explain theories with monotonous teaching methods such as lecture methods and not with scientific approaches that affect students who do not have the skills in experimentation because they are taught only about theory (Darmaji, Kurniawan, Parasdila, \& Irdianti, 2018). When the teaching process of physics is done conventionally, students tend to only master physics concepts without knowing the process of the occurrence of these concepts (Ningsi \& Nasih, 2020). Learning systems that do not provide students with opportunities to understand the concept of science that are essential will cause misunderstanding or misconception (Margunayasa, 2014). Such learning can lead to weak students' science process skills. For this reason, teachers need to teach using the right method so students can understand the concepts of physics, namely using the experimental method. It is also important for the teacher to know the students' science process skills to improve the teacher's way.

Knowledge about static fluid material is not enough for students to only learn theories or concepts, but students need a skill. Learning will be more meaningful if students are allowed to know and are actively involved in finding concepts from existing phenomena from the environment with the guidance of the teacher(Rizal, 2014). Thus to learn these concepts, science process skills are needed. Process skills and scientific attitudes can be developed by providing direct experience to students. One of them is through practical activities or experiments (Hartono \& Oktafianto, 2014). Practical learning physics activities have a motivational role in learning, provide opportunities for students to develop some skills, and improve the quality of student learning (Mustika \& Murniati, 2011). Practicum has three functions: training, giving feedback, and increasing motivation, which in practice requires information processing skills information (Kustijono, 2018). Teaching and learning process with this experimental method, students are allowed to experience themselves or do it themselves, follow a process, observe an object, analyze, prove and draw their conclusions about an object, situation, or process of something (Kurniawati et al., 2015). Practical activities become one of the learning activities for students to develop the ability to think, analyze, solve problems, prove and draw conclusions of an object from the material being studied (Royani et al., 2018). Based on the presentation that science process skills can be measured through practical activities.

Physics learning aims to develop students' scientific inquiry (Sukarno et al., 2013). The skills needed to develop scientific concepts are the skills of the scientific process. Basic science process skills are all actions taken while experimenting (Darmaji, Kurniawan, Astalini, Kurniawan, et al., 2019). Because the beginning of all experimental activity comes from observation, where observation is part of the basic process skills (Monhardt \& Monhardt, 2006). Basic science process skills help students develop learning through direct experience. These basic skills will be the basis for further skill development (Darmaji, Kurniawan, \& Lestari, 2018). If physics students do not master basic learning skills, it will be difficult to develop higher abilities, which will impact student learning outcomes. Based on these considerations, the researcher researched to measure the ability of students' science process skills on static fluid material by using observation sheets that were following indicators of science process skills.

\section{METHOD}

The research method used is a mixture method (mix methods), while the design used is sequential explanatory, which combines quantitative and qualitative research in a sequence using the quantitative method and the quantitative method (Sugiyono, 2006). The use of a sequential explanatory design begins with collecting and analyzing quantitative data followed by the collection and analysis of qualitative data qualitative (Creswell, 2016). In this method, quantitative data is preferred. Quantitative research 
emphasizes numerical assessment and is descriptive (Machmud, 2005). while the qualitative method serves to prove, deepen, and expand quantitative data. The research procedure carried out in this study is to analyze quantitative data first and then to continue to use quantitative data.

Data collection techniques in this study used science process skills observation sheets and interview sheets. Quantitative data collection techniques are using science process skills observation sheets using 16 indicators of science process skills. On the observation sheet, there are 46 statements. Interviews were conducted with two students per class and two teachers teaching physics materials. This study sample were students of grades IX.1, IX.2, IX3 in Adhyaksa 1 Junior High School in Jambi City, which totaled 58 students.

The instrument used in this study was the observation sheet of the science process skills adopted from the thesis Indrawati (2018). What was observed in this study was the process skills students had while conducting practicum activities in the laboratory. Ten observer players assisted this observation. Data on the observation sheet will be analyzed using descriptive statistics. Descriptive statistics display general trends in data to describe one variable (Creswell, 2016). the percentage for each indicator sought is then stated in several categories, namely the Very Not Good (VNG), Not Good (NG), Good (G), Very Good (VG) categories. Science process skills that are focused in this study are divided into two categories, namely basic science process skills and integrated science process skills consisting of 16 indicators, namely basic process skills (Observation, Classification, Measuring, Prediction, Communication, Concluding) integrated science process skills (Identify variables, compile data tables, make graphs, obtain and process data, describe the relationships between variables, define variables operationally, make hypotheses, analyze experiments, devise investigations, conduct experiments). The data obtained are searched for intervals for each indicator then expressed in several categories, such as in the table below. The data obtained are searched for intervals for each indicator then expressed in several categories, such as in the Table 1.

Table 1. The range of Student Science Process Skill in all indicators.

\begin{tabular}{clcccc}
\hline \multirow{2}{*}{$\begin{array}{c}\text { Science } \\
\text { process skills }\end{array}$} & \multicolumn{1}{c}{ Indicator } & \multicolumn{4}{c}{ Interval } \\
\cline { 2 - 5 } Basic & Observation & VNG & NG & $\mathrm{G}$ & VG \\
& classification & $5.00-8.75$ & $8.75-12.50$ & $12.51-16.25$ & $16.26-20.00$ \\
& Measure & $2.00-3.50$ & $3.51-5.00$ & $5.01-6.50$ & $6.51-8.00$ \\
& Prediction & $4.00-7.00$ & $7.01-10.00$ & $10.01-13.00$ & $13.01-16.00$ \\
& Communication & $2.00-3.50$ & $3.51-5.00$ & $5.01-6.50$ & $6.51-8.00$ \\
Integrated & $2.00-3.50$ & $3.51-5.00$ & $5.01-6.50$ & $6.51-8.00$ \\
& Conclude & $2.00-3.50$ & $3.51-5.00$ & $5.01-6.50$ & $6.51-8.00$ \\
& Variable identification & $3.00-5.25$ & $5.26-7.50$ & $7.51-9.73$ & $9.76-12.00$ \\
& Table data compiled & $3.00-5.25$ & $5.26-7.50$ & $7.51-9.73$ & $9.76-12.00$ \\
& Make a graph & $3.00-5.25$ & $5.26-7.50$ & $7.51-9.73$ & $9.76-12.00$ \\
& Accessing and processing data & $2.00-3.50$ & $3.51-5.00$ & $5.01-6.50$ & $6.51-8.00$ \\
& Describe the relationship & & & & \\
& between variables & $5.00-8.75$ & $8.75-12.50$ & $12.51-16.25$ & $16.26-20.00$ \\
& Define variables operationally & $5.00-8.75$ & $8.75-12.50$ & $12.51-16.25$ & $16.26-20.00$ \\
& Make a hypothesis & $2.00-3.50$ & $3.51-5.00$ & $5.01-6.50$ & $6.51-8.00$ \\
& Experiment analysis & $2.00-3.50$ & $3.51-5.00$ & $5.01-6.50$ & $6.51-8.00$ \\
& Designing Investigations & $2.00-3.50$ & $3.51-5.00$ & $5.01-6.50$ & $6.51-8.00$ \\
& conduct experiments & $2.00-3.50$ & $3.51-5.00$ & $5.01-6.50$ & $6.51-8.00$ \\
\hline
\end{tabular}

\section{RESULTS AND DISCUSSION}

Data analysis results on mastery of science process skills in students of inert fluid material that is already classified as good. The results of the minimum and maximum values obtained by students that are seen as in Table 2. Table 2 also displays the results of a descriptive statistical analysis of overall student science process skills.

Table 2, which came from 58 respondents from Adhyaksa 1 Junior High School, students in Jambi City had a Mean value of 2,810, a maximum value of 4.00, and a Minimum Value of 1.00 . Of the 58 student respondents who were categorized very poor as 4 people with a percentage of $6.9 \%$ for the wrong category, as many as 7 students with a percentage of $12.1 \%$ for the good category, as many as 43 students with a percentage of $74.1 \%$ for the very good category as many as 4 students with a percentage of $6.9 \%$. 
The results of the analysis of mastery of students 'science process skills showed that students' science process skills were already classified as good. This is shown from the results of the largest percentage in the good category.

Table 2. Results of descriptive statistical analysis of overall student science process skills

\begin{tabular}{ccccccccc}
\hline Range & Category & f & $\%$ & Mean & Median & Modus & Min & Max \\
\hline $46.00-80.50$ & STB & 4 & 6.9 & & & & & \\
$80.51-115.00$ & TB & 7 & 12.1 & 2.810 & 3.00 & 3.00 & 1.00 & 4.00 \\
$115.01-149.50$ & B & 43 & 74.1 & & & & & \\
$149.51-184.00$ & SB & 4 & 6.9 & & & & \\
\hline
\end{tabular}

Table 3. Mastery of the Science Process Skills of students on a density experiment

\begin{tabular}{clcccc}
\hline \multirow{2}{*}{$\begin{array}{c}\text { Science process } \\
\text { skills }\end{array}$} & \multicolumn{1}{c}{ Indicator } & \multicolumn{3}{c}{ Category } \\
\cline { 3 - 6 } Basic & Observation & NVG (\%) & NG (\%) & G (\%) & VG (\%) \\
& classification & 1.7 & 6.9 & 29.3 & 62.1 \\
& Measure & 12.1 & 41.4 & 19.0 & 27.6 \\
& Prediction & 3.4 & 17.2 & 37.9 & 41.4 \\
& Communication & 5.2 & 27.6 & 20.7 & 44.8 \\
& Conclude & 8.6 & 41.4 & 22.4 & 27.6 \\
Integrated & Variable identification & 8.6 & 34.5 & 27.6 & 29.3 \\
& Table data compiled & 37.9 & 22.4 & 17.2 & 22.4 \\
& Make a graph & 10.3 & 15.5 & 37.9 & 36.2 \\
& Accessing and processing data & 29.3 & 31.0 & 22.4 & 17.2 \\
& Describe the relationship between & 1.7 & 31.0 & 10.3 & 56.9 \\
& variables & 5.2 & 25.9 & 56.9 & 12.1 \\
& Define variables operationally & 3.4 & 15.5 & 50.0 & 31.0 \\
& Make a hypothesis & 10.3 & 31.0 & 20.7 & 37.9 \\
& Experiment analysis & 0 & 17.2 & 8.6 & 74.1 \\
& Designing Investigations & 8.6 & 12.1 & 17.2 & 62.1 \\
& conduct experiments & 8.6 & 22.4 & 8.6 & 60.3 \\
\hline
\end{tabular}

In Table 3 is a table of mastery of students' science process skills in all indicators, 16 indicators are divided into two, namely basic sains process skills (Observation, Classification, Measuring, Prediction, Communication, conclude ) and integrated science process skills (Integrative variables, Table data compiled, Make graphs, Accessing and processing data, Describe relationships between variables, Define variables operationally, Make hypotheses, Analyze experiments, Design Investigations, conduct experiments).

Table 2 shows that the results of students' basic science process skills in the observation indicator are quite good. The observation indicator has a percentage of $62.1 \%$ included in the very good category, $29.3 \%$ included in the good category, $6.9 \%$ included in the not good category, and $1.7 \%$ included in the very not good category. Classifieds indicators are classified as not good because, in this category has the highest percentage. Thus the calcific indicator has a percentage of $27.6 \%$ included in the very good category, $19.0 \%$ included in the good category, $41.1 \%$ included in the not good category, and $12.1 \%$ included in the very not good category. In measuring indicators classified as very good, because in this category has the highest percentage. For measuring indicators, have a percentage of $41.1 \%$ included in the category of very good, $39.7 \%$ included in the good category, $17.2 \%$ included in the not good category, and 3.4\% included in the very not good category. The prediction indicator is classified as very good because in this category has the largest percentage. The prediction indicator has a percentage of $44.8 \%$ included in the very good category, $20.7 \%$ included in the good category, $27.6 \%$ included in the not good category, and 5.2\% included in the very not good category. In the communications, the indicator is not good, because this indicator has the largest percentage. This communication category as a percentage of $27.6 \%$ included in the very good category, $22.4 \%$ included in the good category, $41.4 \%$ included in the not good category, and $8.6 \%$ included in the very not good category. The indicators concluded are not good because in this category has the largest percentage. This category has a percentage of $29.3 \%$ included in the very good category, $27.6 \%$ included in the good category, $34.5 \%$ included in the not good category, and $8.6 \%$ included in the very not good category. 
Jurnal Inovasi Pendidikan IPA, 6 (2), 2020 - 160

Tanti Tanti, Dwi Agus Kurniawan, Aziza Putri Ningsi

The results of science process skills integrated with students in the variable identification indicator are not very good because this category has a percentage. The identification variable has a percentage of $22.4 \%$ included in the very good category, $17.2 \%$ included in the good category, $22.4 \%$ included in the not good category, and $37.9 \%$ included in the very not good category. In the indicator compile the data table is quite good because in this category has the highest percentage. The data table has a percentage of $36.2 \%$ included in the very good category in the indicators compiled, $37.9 \%$ included in the good category, $15.5 \%$ included in the not good category, and $10.3 \%$ included very not a good category in the indicator to make a graph quite good because in this category has the highest percentage. The indicator has a percentage of $17.2 \%$ included in the very good category in the chart, $22.4 \%$ included in the good category, $31.0 \%$ included in the not good category, and $29.3 \%$ included in the very not good category. In the indicator of obtaining and processing data classified as very good, this category has the highest percentage. In the index compile the data table has $56.9 \%$ included in the very good category, $10.3 \%$ included in the good category, $31.0 \%$ included in the not good category, and $1.7 \%$ included in the very not good category. The indicator describes the relationship between variables classified as good because in this category has the highest percentage. The indicator describing the relationship between variables has a percentage of $12.1 \%$ included in the very good category, $56.9 \%$ included in the good category, $25.9 \%$ included in the not good category, and 5.2\% included in the very not good category. The indicator defines variables operationally is classified as good, because in this category has the highest percentage. In the indicator defining operational variables have a percentage of $31.0 \%$ included in the very good category, $50.0 \%$ included in the good category, $15.5 \%$ included in the not good category, and $3.4 \%$ included in the very not good category.

The indicators making hypotheses are classified as very good because in this category have the highest percentage. The indicator defines variables operationally with a percentage of $37.9 \%$ included in the very good category, $20.7 \%$ included in the good category, $31.0 \%$ included in the not good category, and $10.3 \%$ included in the very not good category. The indicator analysis of the experiment is classified as very good because it has the highest percentage in this category. The indicator defines variables operationally with a percentage of $74.1 \%$ included in the very good category, $8.6 \%$ included in the good category, $17.2 \%$ included in the not good category, and\% included in the very not good category. The indicators of designing an investigation are classified as very good because this category has the highest percentage. The indicator defines variables operationally with a percentage of $62.1 \%$ included in the good category, $17.2 \%$ included in the good category, $12.1 \%$ included in the not good category, and $8.6 \%$ included in the very not good category. The indicators of conducting experiments are classified as very good because this category has the highest percentage. The indicators of conducting experiments have a percentage of $60.3 \%$ included in the very good category, $8.6 \%$ included in the good category, $22.4 \%$ included in the not good category, and $8.6 \%$ included in the very not good category. Experiments are the highest skills available in integrated science process skills (Aydın, 2013).

Science process skills are important process skills to be possessed by students (Yadaeni, Kusairi, \& Parno, 2018). Sain process skills can be used by students to solve physical problems in daily life (Zeidan \& Jayosi, 2015). Process skills are acquired skills and basic skills. Where these basic skills will develop higher skills. Linking previous experiences carried out through practical activities is one of physics's characteristics that requires science process skills (Mulhall \& Gunstone, 2012). Science process skills are divided into two parts, namely basic science process skills and integrated science process skills (Turiman et al., 2012). Description of science process skills of junior high school students on static fluid material is presented in table 2 and table 3 with one activity of 16 indicators, namely basic process skills (Observation, Classification, Measuring, Prediction, Communication, Conclude) and integrated science process skills (Integrative variable, Arranging variables Data Tables, Make graphs, Obtain and process data, Describe relationships between variables, Define variables operationally, Make hypotheses, Analyze experiments, Design Investigations, Perform experiments). The importance of science process skills for junior high school students is that students learn meaningfully by knowing and actively discovering concepts from existing phenomena in the environment. Meaningful learners are learning that involves students directly, and learning will be easy to remember. Students who can form science process skills will help students master the next skills (Rubin \& Norman, 1992).

From the results of this study, it can be seen that middle school students' science process skills vary. Ranging from students who are skilled to unskilled. In basic science process skills have 6 indicators, the observation indicator students have the largest percentage of $62.1 \%$ and this is a very 
good category and shows that students are skilled enough in observing. FurtheThey is ranging the classification indicator of students with the largest percentage of $41.4 \%$, which is not good. These results indicate that students' skills on this indicator are low because students have not been able to classify experimental data characteristics. On the indicator measuring, students have a $41.4 \%$ percentage, which is in the very good category. This means that students are already skilled in this indicator because students can measure the length of objects in an experiment student are interested in experiments, so they tend to be active in measurement activities (Ambarsari et al., 2013). In the prediction indicator, students have the largest percentage of $44.8 \%$, and this is in the very good category and shows that students can express the density of objects during the experiment. Prediction is a skill used to predict the consequences of changing circumstances based on the whole (Wiwin \& Kustijono, 2018). Following the communication indicator, students have the largest percentage of $41.4 \%$, which is not good. This means that students are not yet skilled in this indicator and show that students are less discussing the measurement results with friends. The indicator concluded that students had the largest percentage of $34.5 \%$, which was not a good category. This shows that students have not been able to express data in a table to be a conclusion in this indicator.

In addition to basic science process skills, this research also focuses on integrated science process skills. In the experiment, determine the density of objects obtained that the ability to identify variables has a percentage of $37.9 \%$, which is not very good. This means that students have not been able to determine the variables in the experiment. The indicator of compiling the data table has the largest percentage of $37.9 \%$, which is in a good category. This means that students can already create experiment table data. In the graph-making indicator, students have the largest percentage of $31.0 \%$, and this is in the category of not good, meaning that students cannot graph the relationships between variables in this indicator. The indicator of obtaining and processing students has the largest percentage of 56.9\%, which is in the very good category. This means that in this indicator, students can display data in the form of experimental table results.

The indicator describing the relationship between student variables has the largest percentage of $56.9 \%$, which is in a good category. This means that in this indicator, students can criticize the use of equations in experiments. The indicator defines variables operationally. Students have the largest percentage of $50.0 \%$, and this is in the very good category. It means that in this indicator, students can measure all the variables in the experiment. Defining variables operationally determines the independent variable, the dependent variable, the control variable (Duruk et al., 2017). On the indicator of making hypotheses, students have the largest presence, which is $37.9 \%$, and this is in the very good category. This means that in this indicator, students have adjusted the design of the experiment with the hypothesis. In the experimental analysis indicator, students have the largest percentage of $74.1 \%$, which is in the very good category. This means that on this indicator, students can take the tools and experimental material. In the indicators of designing experiments, students have the largest percentage of $62.1 \%$, and this is in the very good category. This means that in this indicator, students can determine the tools and materials for the experiment. Furthermore, the last one, the actor, experimented with students who had the largest percentage of $60.3 \%$, which was in the very good category. This means that on this indicator, students can carry out experimental activities.

In this experiment using 16 indicators of process skills. There are 6 indicators of basic science process skills. In the observation indicator, measuring predictions fall into the excellent category. This means that in these 3 indicators, students are already skilled. At the same time, the integrated science process skills are 10 indicators. The indicators compile data tables, make graphs, obtain and process data, describe relationships between variables, define variables operationally, make hypotheses, analyze experiments, design investigations, conduct experiments included in either category. This means that on these indicators, students are already selected. Observation skills are the most basic skills that support the mastery of different skills, namely, integrity process skills. (Zeidan \& Jayosi, 2015) basic process skills support the developing other skills, namely integrated process skills. When students are already skilled in basic science process skills, the integrated science process skills will be good.

Researchers also conducted interviews with two students to see students' science process skills. From the interviews, it can be seen that, through the curriculum's activities, it can be seen that the science process skills of Adhyaksa 1 Junior High School students in the city of Jambi have been classified as good. In understanding concepts, students not only memorize formulas without regard to understanding the concept or understanding the physical meaning of the formula correctly. 


\section{Jurnal Inovasi Pendidikan IPA, 6 (2), 2020 - 162}

Tanti Tanti, Dwi Agus Kurniawan, Aziza Putri Ningsi

Researchers also conducted interviews with teachers to see science process skills. Teachers often hold practicum activities but not all material. When practicum activities occur, students follow each activity, so they are already skilled in using practical tools. Thus when practicum activities take place, most of the students actively participate in measuring and concluding activities. To support practicum activities, laboratory rooms and equipment must be complete. From the results of interviews and observations, it can be seen that the science process skills of students at Adhyaksa 1 Junior High School in Jambi are classified as good.

\section{CONCLUSION}

The research aims to measure the ability of students' science process skills on static fluid material by using an observation sheet that matches the indicators of science process skills. The research method used is a mixed-method (mixed methods). In contrast, the design used is sequential explanatory, which combines quantitative and qualitative research in a sequence using the quantitative method and then the quantitative method. From the results of interviews and observations, it can be seen that the science process skills of students at Adhyaksa 1 Junior High School in Jambi are classified as good. Basic science process skills classified as good are found in indicators (observation, measuring predictions).

In contrast, integrated science process skills are found in indicators (compile data tables, graphs, obtain and process data, describe relationships between variables, define variables operationally, make hypotheses, experimental analysis, planning investigations, conducting experiments). The importance of science process skills for junior high school students is that students learn meaningfully by knowing and actively discovering concepts from phenomena in the environment. Meaningful learners are learning that involves students directly, and learning will be easy to remember.

\section{REFERENCES}

Ambarsari, W., Santosa, S., \& Maridi, M. (2013). Penerapan pembelajaran inkuiri terbimbing terhadap keterampilan proses sains dasar pada pelajaran biologi siswa kelas VIII SMP Negeri 7 Surakarta. Jurnal Pendidikan Biologi, 5(1), 81-95. https://jurnal.uns.ac.id/bio/article/view/5626

Asrial, A., Syahrial, S., Kurniawan, D. A., Perdana, R., \& Nugroho, P. (2019). Supporting Technology 4.0: Ethoconstructivist multimedia for elementary schools. International Journal of Online and Biomedical Engineering (IJOE), 15(14), 54. https://doi.org/10.3991/ijoe.v15i14.11365

Astalini, A., Kurniawan, D. A., \& Putri, A. D. (2018). Identifikasi sikap implikasi sosial dari IPA, ketertarikan menambah waktu belajar IPA, dan ketertarikan berkarir dibidang ipa siswa SMP se-Kabupaten Muaro Jambi. Jurnal Tarbiyah: Jurnal Ilmiah Kependidikan, 7(2), 93-108.

Astalini, A., Kurniawan, D. A., \& Sumaryanti, S. (2018). Sikap siswa terhadap pelajaran fisika di SMAN Kabupaten Batanghari. JIPF (Jurnal Ilmu Pendidikan Fisika), 3(2), 59. https://doi.org/10.26737/jipf.v3i2.694

Aydın, A. (2013). Representation of science process skills in the chemistry curricula for grades 10, 11 and 12/Turkey. International Journal of Education and Practice, 1(5), 51-63. https://doi.org/10.18488/journal.61/2013.1.5/61.5.51.63

Chabalengula, V. M., Mumba, F., \& Mbewe, S. (2012). How pre-service teachers' understand and perform science process skills. EURASIA Journal of Mathematics, Science and Technology Education, 8(3), 167-176. https://doi.org/10.12973/eurasia.2012.832a

Creswell, J. W. (2016). Research design: pendekatan kualitatif, kuantitatif, dan mixed. Pustaka Pelajar.

Darmaji, D., Kurniawan, D. A., Astalini, A., Kurniawan, W., Anwar, K., \& Lumbantoruan, A. (2019). Students' perceptions of electronic's module in physics practicum. Journal of Education and Learning (EduLearn), 13(2), 288. https://doi.org/10.11591/edulearn.v13i2.13005

Darmaji, D., Kurniawan, D. A., Astalini, A., \& Nasih, N. R. (2019). Persepsi mahasiswa pada penuntun praktikum fisika dasar II berbasis mobile learning. Jurnal Pendidikan: Teori, Penelitian, Dan Pengembangan, 4(4), 516-523. https://doi.org/10.17977/jptpp.v4i4.12345

Darmaji, D., Kurniawan, D. A., \& Lestari, A. (2018). Deskripsi keterampilan proses sains mahasiswa pendidikan fisika pada praktikum suhu dan kalor. Jurnal Riset Dan Kajian Pendidikan Fisika, 


\section{Jurnal Inovasi Pendidikan IPA, 6 (2), 2020 - 163}

Tanti Tanti, Dwi Agus Kurniawan, Aziza Putri Ningsi

5(2), 68. https://doi.org/10.12928/jrkpf.v5i2.10735

Darmaji, D., Kurniawan, D. A., Parasdila, H., \& Irdianti, I. (2018). Description of science process skills' physics education students at Jambi University in temperature and heat materials. Educational Review, USA, 2(9), 485-498. https://doi.org/10.26855/er.2018.09.004

Darmaji, D., Kurniawan, D. A., Suryani, A., \& Lestari, A. (2018). An identification of physics preservice teachers' science process skills through science process skills-based practicum guidebook. Jurnal Ilmiah Pendidikan Fisika Al-Biruni, 7(2), 239. https://doi.org/10.24042/jipfalbiruni.v7i2.2690

Duruk, U., Akgün, A., Dogan, C., \& Gülsuyu, F. (2017). Examining the learning outcomes included in the Turkish science curriculum in terms of science process skills: A document analysis with standards-based assessment. International Journal of Environmental and Science Education, 12(2), 117-142.

Halim, A. (2012). Pengaruh strategi pembelajaran dan gaya belajar terhadap hasil belajar fisika siswa SMPN 2 Secanggang Kabupaten Langkat. Jurnal Tabularasa, 9(2), 141-158.

Hartono, H., \& Oktafianto, W. R. (2014). Kefektifan pembelajaran praktikum IPA berbantu LKS discovery untuk mengembangkan keterampilan proses sains. Unnes Physics Education Journal, 3(1). https://doi.org/10.15294/upej.v3i1.3104

Hırça, N. (2012). The influence of hands on physics experiments on scientific process skills according to prospective teachers' experiences. European Journal of Physics Education, 4(1), 1-9. http://www.eu-journal.org/index.php/EJPE/article/view/77

Indrawati, P. S. (2018). Pengembangan penuntun praktikum fisiska dasar I berbasis keterampilan proses sains menggunakan model pembelajaran berbasis masalah pada materi kerapatan. Unversitas Negri Jambi.

Kurniawati, L., Akbar, R. O., \& Ali Misri, M. (2015). Pengaruh penerapan metode pembelajaran praktikum terhadap keterampilan berpikir kritis matematika siswa kelas VIII SMP N 3 Sumber Kabupaten Cirebon. Eduma: Mathematics Education Learning and Teaching, 4(2), 62-74. https://doi.org/10.24235/eduma.v4i2.30

Kustijono, R. (2018). The effect of scientific attitudes toward science process skills in basic physics practicum by using peer model. International Journal of GEOMATE, 15(50), 82-87. https://doi.org/10.21660/2018.50.IJCST50

Machmud, M. (2005). Tuntunan penulisan tugas akhir berdasarkan prinsip dasar penelitian ilmiah. Selaras.

Maison, M., Darmaji, D., Astalini, A., Kurniawan, D. A., \& Indrawati, P. S. (2019). Science process skills and motivation. Humanities \& Social Sciences Reviews, 7(5), 48-56. https://doi.org/10.18510/hssr.2019.756

Margunayasa, I. G. (2014). Pengaruh petunjuk praktikum IPA bermuatan perubahan konseptual terhadap peningkatan pemahaman konsep IPA pada mahasiswa PGSD. JPI (Jurnal Pendidikan Indonesia), 3(1), 348-358. https://doi.org/10.23887/jpi-undiksha.v3i1.2917

Monhardt, L., \& Monhardt, R. (2006). Creating a context for the learning of science process skills through picture books. Early Childhood Education Journal, 34(1), 67-71. https://doi.org/10.1007/s10643-006-0108-9

Mulhall, P., \& Gunstone, R. (2012). Views about learning physics held by physics teachers with differing approaches to teaching physics. Journal of Science Teacher Education, 23(5), 429449. https://doi.org/10.1007/s10972-012-9291-2

Mustika, I., \& Murniati, N. A. N. (2011). Upaya meningkatkan hasil belajar IPA-fisika melalui pembelajaran praktikum dengan memanfaatkan alat dan bahan di lingkungan sekitar pada siswa kelas VII SMP Negeri 4 Kragan Rembang tahun ajaran 2008/20091. 2(1), 89-99.

Ningsi, A. putri, \& Nasih, N. R. (2020). Mendeskripsikan keterampilan proses sains mahasiswa pendidikan fisika Universitas Jambi pada metari pembiasan pada lensa cembung dengan menggunakan e-modul. EKSAKTA :Jurnal Penelitian Dan Pembelajaran MIPA, 5(1), 35-43.

Putra, D. S., Lumbantoruan, A., \& Samosir, S. C. (2019). Deskripsi sikap siswa: Adopsi sikap ilmiah, 


\section{Jurnal Inovasi Pendidikan IPA, 6 (2), 2020 - 164}

Tanti Tanti, Dwi Agus Kurniawan, Aziza Putri Ningsi

ketertarikan memperbanyak waktu belajar fisika dan ketertarikan berkarir di bidang fisika.

Tarbiyah : Jurnal Ilmiah Kependidikan, 8(2), 91. https://doi.org/10.18592/tarbiyah.v8i2.3339

Raj, R. G., \& Devi, S. N. (2014). Science process skills and achievement in science among high. Scholarly Research Journal for Interdisciplinary Studies, 2(15), 2435-2443.

Rizal, M. (2014). Pengaruh pembelajaran inkuiri terbimbing dengan multi representasi terhadap keterampilan proses sains dan penguasaan konsep IPA siswa SMP. Jurnal Pendidikan Sains, 2(4), 159-165.

Rosa, F. O. (2015). Pengembangan modul pembelajaran IPA SMP pada materi tekanan berbasis keterampilan proses sains. Jurnal Pendidikan Fisika, 3(1). https://doi.org/10.24127/jpf.v3i1.21

Royani, I., Mirawati, B., \& Jannah, H. (2018). Pengaruh model pembelajaran langsung berbasis praktikum terhadap keterampilan proses sains dan kemampuan berpikir kritis siswa. Prisma Sains : Jurnal Pengkajian Ilmu Dan Pembelajaran Matematika Dan IPA IKIP Mataram, 6(2), 46. https://doi.org/10.33394/j-ps.v6i2.966

Rubin, R. L., \& Norman, J. T. (1992). Systematic modeling versus the learning cycle: Comparative effects on integrated science process skill achievement. Journal of Research in Science Teaching, 29(7), 715-727. https://doi.org/10.1002/tea.3660290708

Sambada, D. (2012). Peranan kreativitas siswa terhadap kemampuan memecahkan masalah fisika dalam pembelajaran kontekstual. Jurnal Penelitian Fisika Dan Aplikasinya (JPFA), 2(2), 37. https://doi.org/10.26740/jpfa.v2n2.p37-47

Sugiyono, S. (2006). Statistika untuk penelitian. CV. Alfabeta.

Sukarno, S., Permanasari, A., \& Hamidah, I. (2013). Science teacher understanding to science process skills and implications for science learning at junior high school (case study in Jambi). International Journal of Science and Research (IJSR), 2(6), 450-454. https://www.ijsr.net/archive/v2i6/IJSRON20131132.pdf

Turiman, P., Omar, J., Daud, A. M., \& Osman, K. (2012). Fostering the 21st century skills through scientific literacy and science process skills. Procedia - Social and Behavioral Sciences, 59, 110-116. https://doi.org/10.1016/j.sbspro.2012.09.253

Wiwin, E., \& Kustijono, R. (2018). The use of physics practicum to train science process skills and its effect on scientific attitude of vocational high school students. Journal of Physics: Conference Series, 997, 012040. https://doi.org/10.1088/1742-6596/997/1/012040

Yadaeni, A., Kusairi, S., \& Parno, P. (2018). Penguasaan konsep dan keterampilan proses sains siswa kelas XII pada materi fluida statis. Jurnal Pendidikan: Teori, Penelitian, Dan Pengembangan, 3(3), 357-364. https://doi.org/10.17977/jptpp.v3i3.10657

Yediarani, R. D., Maison, M., \& Syarkowi, A. (2019). Scientific reasoning abilities profil of junior high school students in Jambi. Indonesian Journal of Science and Education, 3(1), 21. https://doi.org/10.31002/ijose.v3i1.627

Yuliati, Y. (2016). Peningkatan keterampilan proses sains siswa sekolah dasar melalui model pembelajaran berbasis masalah. Jurnal Cakrawala Pendas, 2(2). https://doi.org/10.31949/jcp.v2i2.335

Zeidan, A. H., \& Jayosi, M. R. (2015). Science process skills and attitudes toward science among palestinian secondary school students. World Journal of Education, 5(1), 13-24. https://doi.org/10.5430/wje.v5n1p13 